\title{
Huanglongbing-related Responses of 'Valencia' Sweet Orange on Eight Citrus Rootstocks during Greenhouse Trials
}

\author{
Ed Stover ${ }^{1,5}$, David G. Hall ${ }^{1}$, Jude Grosser ${ }^{2}$, Barrett Gruber ${ }^{3}$, \\ and Gloria A. Moore ${ }^{4}$
}

AdDitional Index words. Candidatus Liberibacter asiaticus, citrus greening, Citrus sinensis, disease tolerance, huanglongbing

SUMMARY. The primary objective of this experiment was to determine if the selection of rootstock (Citrus and hybrids) could enhance the development of huanglongbing (HLB)-related symptoms associated with the pathogen Candidatus Liberibacter asiaticus (CLas) in sweet orange (Citrus sinensis). If so, then it may permit more rapid identification of HLB-susceptible compared to HLB-resistant scion types. The secondary objective was to assess the impact of different rootstocks on plant growth parameters and health to determine if trees on any rootstocks displayed reduced sensitivity to HLB-influenced growth restriction. 'Valencia' sweet orange was budded on each of the following eight genotypes: Carrizo (C. sinensis $\times$ Poncirus trifoliata); Cleopatra (C. reshni); Green-7 \{a complex allotetraploid from somatic hybrids [C. clementina $\times($ C. paradisi $\times$ C. veticulata $)+C$. grandis] $\times$ $[($ C. aurantium + (C. sinensis $\times$ P. trifoliata) $]\}$; UFR-2 (a complex allotetraploid from somatic hybrids $\{[$ C. clementina $\times($ C. paradis $\times$ C. reticulata $)]+$ C.grandis $\}$ $\times($ C. reticulata + P. trifoliata)); UFR-4 (same pedigree as UFR-2); rough lemon (C. jambbivi); sour orange (C. aurantium); and US-897 (C. veticulata $\times P$. trifoliata). Half of the trees on each rootstock were bud-inoculated with CLas and half were inoculated with the asian citrus psyllid [ACP (Diaphorina citri)], which is the CLas vector. During both experiments, no rootstock conferred significantly greater HLB symptom severity compared to trees on Carrizo; however, trees on several rootstocks had reduced HLB severity compared to those on Carrizo.

Regarding the bud-inoculated trees after 3 years, trees on UFR-4 displayed greater overall health than trees on Carrizo, Green-7, sour orange, and US897, and trees on UFR-4 had a higher percentage of plants with leaf cycle threshold $(\mathrm{Ct})$ values $>36$ compared with trees on Cleopatra and rough lemon (62 vs. 26-29 respectively). Regarding the ACP-inoculated trees after 3 years, trees on UFR-4 had better overall health than trees on Carrizo, rough lemon, and US-897, and trees on sour orange had a higher percentage of plants with leaf Ct values greater than 36 only compared to Cleopatra and US-897. The percentage increase in the trunk diameter per month over the course of each entire experiment was significantly greater for UFR-2 in both trials than all rootstocks except UFR-4. Only root CLas titers were sometimes significantly higher for trees on other rootstocks compared to those on Carrizo. Although no rootstock provided acceleration of HLB symptom development compared with Carrizo, some rootstocks conferred significantly greater health compared to Carrizo. However, it is uncertain whether the modest differences in health and growth observed in these greenhouse trials would translate to economic benefits in the field.

$\mathrm{T}$ The disease huanglongbing has devastated the Florida citrus industry. Yields of the 201718 cropping season were reduced $75 \%$ compared with the peak observed since HLB was first found in Florida (U.S. Department of Agriculture, 2018a, 2018b). HLB in Florida is associated with Candidatus Liberibacter asiaticus, and it is vectored by the asian citrus psyllid. After the initial infection, many months may pass before typical blotchy mottle symptoms on the leave are evident. Trees affected by HLB are usually less vigorous, display root decline, have thinning canopies, have asymmetric chlorosis of leaves, and produce fruit with decreased yield and quality (Bové, 2006; Gottwald, 2010). Sweet orange and grapefruit (Citrus paradisi) cultivars are especially susceptible.

Insecticidal vector control and production practices to reduce stress are the primary components of HLB management in Florida. Production costs for Florida citrus have greatly increased; HLB has caused the costs of central Florida processing of sweet orange production to increase an average of $\approx 2.5$ times (Singerman, 2016). Furthermore, compared to healthy orchards, infected orchard productivity has been estimated to be only $59 \%$ (Singerman and Useche, 2015). Sustainability of citrus production where HLB is endemic is likely to require the use of citrus cultivars that are HLB-resistant or HLB-tolerant (Gottwald, 2010).

HLB susceptibility has been reported to vary within the genus Citrus and its relatives (Albrecht et al., 2012; Folimonova et al., 2009; Ramadugu et al., 2016; Stover and McCollum, 2011; Stover et al., $2012,2015,2016 a)$. Therefore, the use of tolerant cultivars may permit profitable citrus production. Even in highly susceptible sweet orange selections, a high level of CLas infection is not often apparent until 8-10 months after the initial infection. Some nongrafted/budded rootstock types are HLB-tolerant (Albrecht and Bowman, 2011; Folimonova et al., 2009); however, it is less certain whether rootstocks markedly affect scion tolerance. There are reports that some rootstocks confer HLB tolerance to susceptible scions (Albrecht, 2017; Bowman et al., 2016; Florida Foundation Seed Producers, 2014). Therefore, some rootstocks may significantly accelerate the development of HLB-related symptoms. Unfortunately, screening for HLB resistance and HLB tolerance is neither quick nor efficient. Our study aimed to determine if any of a series of diverse rootstocks has the potential to accelerate development of HLB symptoms such as a blotchy mottle pattern on the leaves and diminished growth of inoculated trees.

\begin{tabular}{llll}
\hline $\begin{array}{l}\text { Units } \\
\begin{array}{l}\text { To convert U.S. to SI, } \\
\text { multiply by }\end{array}\end{array}$ & U.S. unit & SI unit & $\begin{array}{l}\text { To convert SI to U.S., } \\
\text { multiply by }\end{array}$ \\
\hline 2.54 & inch(es) & $\mathrm{cm}$ & 0.3937 \\
25.4 & inch $(\mathrm{es})$ & $\mathrm{mm}$ & 0.0394 \\
28.3495 & $\mathrm{oz}$ & $\mathrm{g}$ & 0.0353 \\
$2.8350 \times 10^{7}$ & $\mathrm{Oz}$ & ${ }^{\mu g}$ & $3.5274 \times 10^{-8}$ \\
$\left({ }^{\circ} \mathrm{F}-32\right) \div 1.8$ & ${ }^{\circ} \mathrm{F}$ & ${ }^{\circ} \mathrm{C}$ & $\left({ }^{\circ} \mathrm{C} \times 1.8\right)+32$
\end{tabular}

Hortlechnology · December 2018 28(6) 
Such rootstocks would expedite the search for new scions to replace those susceptible to HLB.

\section{Materials and methods}

EXPERIMENTAL MATERIAL. Liners were grown from seeds of Carrizo, Cleopatra, Green-7 from the University of Florida (Citrus Research and Education Center, Lake Alfred, FL), UFR-2, UFR-4, rough lemon, sour orange, and US-897. As with most commercial rootstock liners, seeds were sourced from field trees, and no seedling showed any evidence of HLB before inoculation. Trees were maintained with no insecticide applications in an ACP/HLB-free greenhouse. In Feb. 2013, all trees were budded with clean 'Valencia' (clone 1-14-19) budwood, generating $\approx 50$ trees on each rootstock grown in an ACP-excluding greenhouse. Plants were grown in a soil-less mix (ProMix BX; Premier Tech Horticulture, Quakertown, PA) in 10- $\times 10-\times 34-$ $\mathrm{cm}$ pots. Twenty-five trees on each rootstock were bud-inoculated with two buds [citron (C. medica) and rough lemon] from greenhousegrown plants that tested positive for CLas in Sept. 2013. The original CLas inoculum was from infected 'Lisbon' lemons (C. limon) grown near Ft. Pierce, FL (Albrecht and Bowman, 2008), with infected trees sustained through serial graft

This research was presented at the 2018 annual meeting of the Florida State Horticultural Society.

We thank Regina Tracy, Ashley Witkowski, Ellen Cochrane, Kathy Moulton, and Diane Helseth for their technical assistance, and Rich Marini for his assistance with repeated measures statistical analysis.

This project that was funded in part by the USDA/ APHIS.

The USDA is an equal opportunity provider and employer. The mention of trade names or commercial products in this article is solely for the purpose of providing specific information and does not imply recommendation or endorsement by the U.S. Department of Agriculture.

${ }^{1}$ U.S. Horticultural Research Laboratory, U.S. Department of Agriculture, Agricultural Research Service, 2001 South Rock Road, Fort Pierce, FL 34945

${ }^{2}$ University of Florida, Citrus Research and Education Center, 700 Experiment Station Road, Lake Alfred, FL 33850

${ }^{3}$ University of Florida, Indian River Research and Education Center, 2199 S. Rock Road, Fort Pierce, FL 34945

${ }^{4}$ Horticultural Sciences Department, 1111 Fifield Hall, P.O. Box 110690, University of Florida, Gainesville, FL 32611

${ }^{5}$ Corresponding author. E-mail: Ed.Stover@ars.usda. gov

https://doi.org/10.21273/HORTTECH04137-18
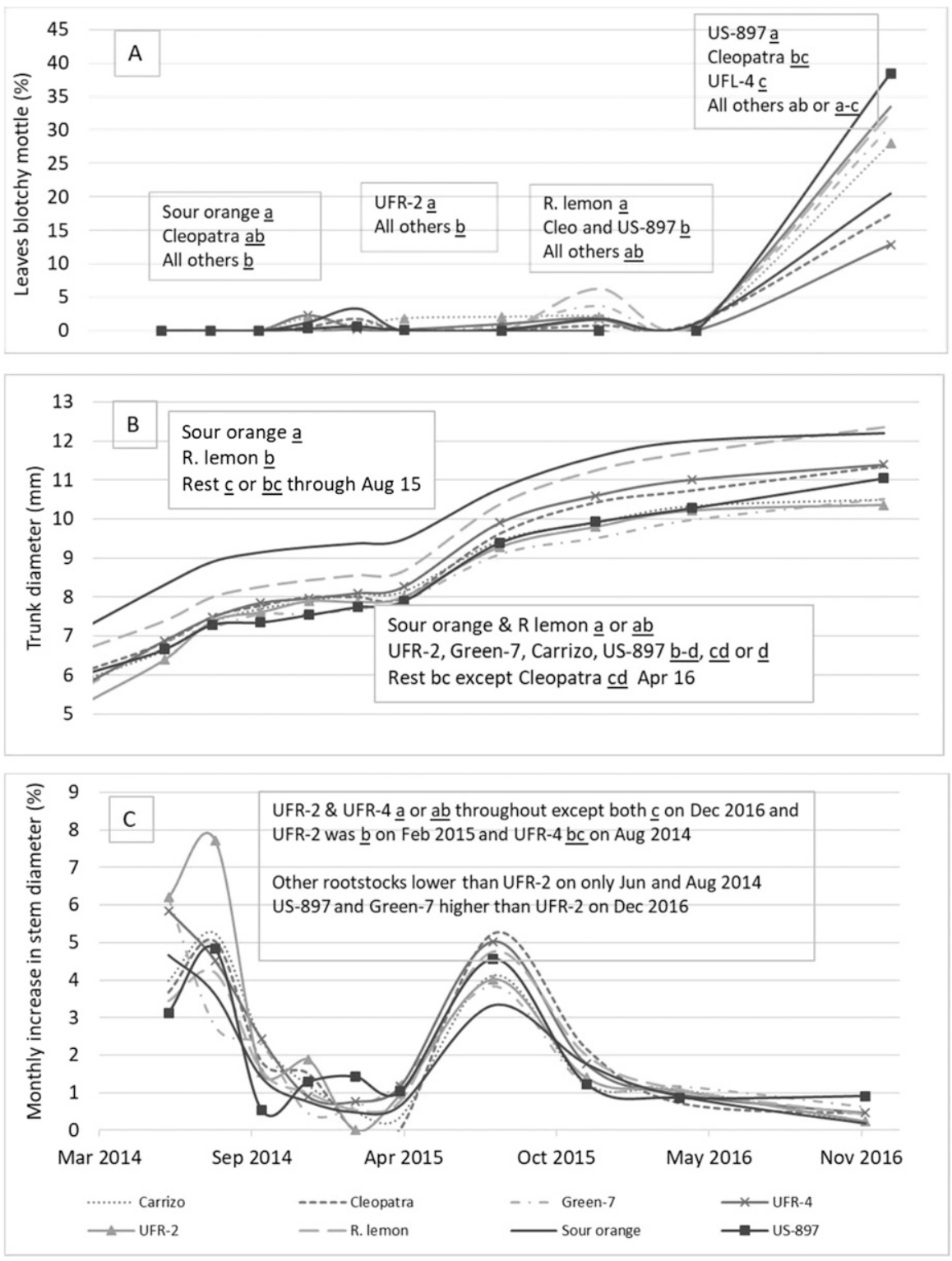

Fig. 1. 'Valencia' sweet orange trees on eight diverse rootstocks inoculated with the huanglongbing pathogen through budding with infected buds and grown in the greenhouse: $(A)$ percentage of leaves showing blotchy mottle; (B) trunk diameter; and (C) monthly percentage change in trunk diameter. Selected mean separations: trunk diameter analyzed using analysis of variance and Duncan's multiple range test; percentage of leaves showing blotchy mottle, and monthly percentage change in trunk diameter analyzed using the Kruskal-Wallis test. Means on the same date are not significantly different at $P=0.050$ if they are followed by the same letter; $1 \mathrm{~mm}=0.0394 \mathrm{inch}$.

transmission. A similar number of trees were ACP-inoculated using psyllids from a CLas-infected colony maintained at the U.S. Horticultural Research Laboratory (Fort Pierce, FL), with CLas isolates initially from budwood collected from the same infected 'Lisbon' lemon trees. Seven to nine trees of each combination were inoculated in Aug. 2013, but ACP colony collapse delayed inoculation of the remainder until Feb. 2014.
During infection, each tree was individually contained within a small cage with 15 ACP from the infected colony and maintained for 2 weeks under lights in the laboratory, as described by Hall and Moulton (2018). Trees were sprayed with carbaryl to kill all ACP and returned to individual cages. After an additional week, carbaryl was sprayed again to eliminate potential surviving ACP. Then, trees were transferred to the greenhouse. 


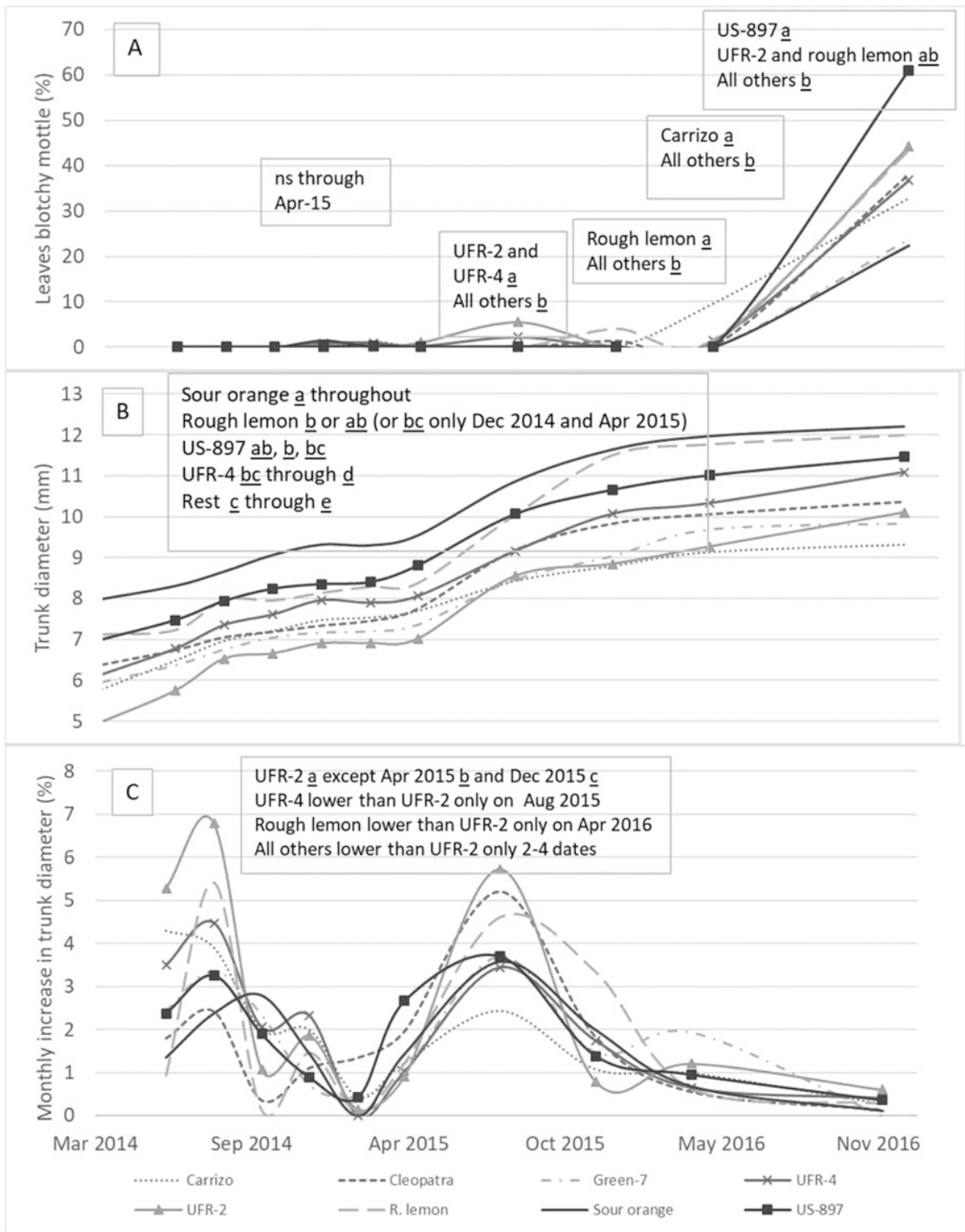

Fig. 2. 'Valencia' sweet orange trees on eight diverse rootstocks inoculated with the huanglongbing pathogen through infection with asian citrus psyllid and grown in the greenhouse: (A) percentage of leaves showing blotchy mottle; (B) trunk diameter; and $(\mathrm{C})$ monthly percentage change in trunk diameter. Selected mean separations: trunk diameter analyzed using analysis of variance and Duncan's multiple range test; percentage of leaves showing blotchy mottle, and monthly percentage change in trunk diameter analyzed using the Kruskal-Wallis test. Means on the same date are not significantly different at $P=0.050$ if they are followed by the same letter; $1 \mathrm{~mm}=0.0394$ inch .

Test trees had a diameter of 4 to $7 \mathrm{~mm}$ and a height of $\approx 0.5 \mathrm{~m}$ at the time of inoculation. All experimental trees were maintained in a greenhouse at the University of Florida Indian River Research and Education Center (Fort Pierce, FL) through Apr. 2015. Then, they were transferred to the U.S. Horticultural Research Laboratory. Trees were maintained with a completely randomized design, mostly at an ambient temperature and humidity with thermostat-controlled fans (starting at $92{ }^{\circ} \mathrm{F}$ ) and heating (starting at $67^{\circ} \mathrm{F}$ ). The greenhouse exterior was white-washed in late spring. Irrigation was typically performed every other day and applied until water drained through pots. The irrigation frequency was adjusted based on environmental conditions and based on the experience of the greenhouse staff. Liquid fertilizer was applied every 3 weeks using $20 \mathrm{~N}-4.4 \mathrm{P}-16.6 \mathrm{~K}$ [total $6 \mathrm{~g}$ nitrogen per pot per year (Peter's
Professional 20-10-20; ICL Specialty Fertilizers, Dublin, $\mathrm{OH}$ )] and BrandtMicrokey mixed chelated micronutrients [0.6 g of iron per pot per year (Brandt Consolidated, Springfield, IL)]. Trees were pruned to a uniform height every 4-6 months as needed to maintain potted trees.

Assessment. Beginning in Mar. 2014, stem diameters were periodically measured and HLB visible leaf symptoms were observed. All stem diameters were determined using the average of two perpendicular (i.e., east-west and north-south) measurements at $5 \mathrm{~cm}$ above the soil surface, which was just above the graft union on the budded trees. HLB leaf symptoms were assessed by visually estimating the percentage of leaves exhibiting blotchy mottle symptoms. The final complete data collection was performed in Dec. 2016, and a 5point assessment of overall tree health was also performed $(1=$ near death, $2=$ severe canopy loss, $3=$ intermediate canopy loss, $4=$ slight canopy loss, and $5=$ fully healthy).

Determination of Clas titer. CLas titers vary throughout the tree (Kunta et al., 2014); therefore, three leaves per tree with the most HLBlike symptoms were randomly selected at each time point (Stover and McCollum, 2011) because random leaves would often include young flush on these small trees. On 12 Jan. 2015, roots were sampled by removing trees from pots and sampling fibrous roots (1-2 $\mathrm{mm}$ in diameter) in the middle exterior of the root mass. All tissue samples were stored in a freezer at $-20^{\circ} \mathrm{C}$ until processed. Each leaf sample was extracted using the bottom $2 \mathrm{~cm}$ of the leaf petiole into the midrib tissue of each of the three leaves. Entire root samples were extracted. Deoxyribonucleic acid (DNA) extraction, quantitative polymerase chain reaction (qPCR) amplification for the quantification of CLas DNA, and analyses were performed as described by Stover et al. (2016b).

Statistical analysis. A statistical analysis was conducted using analysis of variance (Proc GLM) for parametric tree diameter data, and the nonparametric Kruskal-Wallis test (Proc Glimmix) was performed for all other data using SAS (version 9.4; SAS Institute, Cary, NC). The stem diameter measurements were 
Table 1. Performance of 'Valencia' sweet orange on eight rootstocks following bud inoculation with Candidatus Liberibacter asiaticus.

\begin{tabular}{|c|c|c|c|c|c|}
\hline \multirow[b]{2}{*}{$\underline{\text { Rootstock }}$} & \multicolumn{4}{|c|}{ Dec. 2016} & \multirow[b]{2}{*}{$\begin{array}{c}\text { Monthly relative } \\
\text { trunk growth rate (\%) }\end{array}$} \\
\hline & Mortality (\%) & Trunk diam $(\mathrm{mm})^{\mathrm{z}}$ & Tree health $(1-5 \text { scale })^{\mathrm{y}}$ & $\begin{array}{c}\text { Leaves with blotchy } \\
\text { mottle (\%) }\end{array}$ & \\
\hline Cleopatra & $12 \mathrm{ab}$ & $11.4 \mathrm{bc}$ & $3.5 \mathrm{ab}$ & $17 \mathrm{bc}$ & $2.1 \mathrm{bc}$ \\
\hline Green-7 & $5 \mathrm{~b}$ & $10.5 \mathrm{~cd}$ & $3.2 \mathrm{bc}$ & $31 \mathrm{ab}$ & $2.1 \mathrm{bc}$ \\
\hline Rough lemon & $12 \mathrm{ab}$ & $12.3 \mathrm{a}$ & $3.3 \mathrm{ab}$ & $33 \mathrm{ab}$ & $1.9 \mathrm{c}$ \\
\hline UFR-4 & $4 \mathrm{~b}$ & $11.4 \mathrm{bc}$ & $3.7 \mathrm{a}$ & $13 \mathrm{c}$ & $2.4 \mathrm{ab}$ \\
\hline US-897 & $27 \mathrm{a}$ & $11.0 \mathrm{~b}-\mathrm{d}$ & $3.2 \mathrm{bc}$ & $38 \mathrm{a}$ & $2.0 \mathrm{c}$ \\
\hline
\end{tabular}

${ }^{\mathrm{z}} 1 \mathrm{~mm}=0.0394$ inch.

y Visual scale: 1 = severe decline, 5 = fully healthy

${ }^{\mathrm{x}}$ Means followed by the same letter within each column are not statistically significantly different at $P=0.050$. Trunk diameter was assessed by analysis of variance. All others were assessed by the Kruskal-Wallis test.

Table 2. Performance of 'Valencia' sweet orange on eight rootstocks following inoculation with Candidatus Liberibacter asiaticus through feeding by asian citrus psyllid.

\begin{tabular}{lccccc}
\hline & \multicolumn{5}{c}{ Dec. 2016 } \\
\cline { 2 - 5 } Rootstock & Mortality (\%) & Trunk diam $(\mathbf{m m})^{\mathbf{z}}$ & $\begin{array}{c}\text { Tree health } \\
(\mathbf{1}-\mathbf{5} \text { scale) }\end{array}$ & $\begin{array}{c}\text { Leaves with } \\
\text { blotchy mottle (\%) }\end{array}$ & Monthly relative trunk growth rate (\%) \\
\hline Carrizo & $10 \mathrm{~b}^{\mathrm{x}}$ & $9.3 \mathrm{~d}$ & $2.6 \mathrm{c}$ & $33 \mathrm{bc}$ & $1.9 \mathrm{~b}$ \\
Cleopatra & $28 \mathrm{ab}$ & $10.4 \mathrm{~cd}$ & $2.9 \mathrm{a}-\mathrm{c}$ & $38 \mathrm{bc}$ & $1.7 \mathrm{~b}$ \\
Green-7 & $21 \mathrm{ab}$ & $9.8 \mathrm{~d}$ & $2.9 \mathrm{a}-\mathrm{c}$ & $24 \mathrm{c}$ & $1.7 \mathrm{~b}$ \\
Rough lemon & $33 \mathrm{ab}$ & $12.0 \mathrm{ab}$ & $2.8 \mathrm{bc}$ & $43 \mathrm{ab}$ & $1.6 \mathrm{~b}$ \\
Sour orange & $13 \mathrm{ab}$ & $12.2 \mathrm{a}$ & $3.0 \mathrm{ab}$ & $22 \mathrm{~b}$ & $1.6 \mathrm{~b}$ \\
UFR-2 & $37 \mathrm{a}$ & $10.1 \mathrm{~cd}$ & $3.0 \mathrm{a}-\mathrm{c}$ & $44 \mathrm{ab}$ & $2.5 \mathrm{a}$ \\
UFR-4 & $33 \mathrm{ab}$ & $11.1 \mathrm{bc}$ & $3.4 \mathrm{a}$ & $37 \mathrm{bc}$ & $2.0 \mathrm{ab}$ \\
US-897 & $17 \mathrm{ab}$ & $11.5 \mathrm{ab}$ & $2.7 \mathrm{bc}$ & $61 \mathrm{a}$ & $1.8 \mathrm{~b}$ \\
\hline
\end{tabular}

${ }^{\mathrm{z}} 1 \mathrm{~mm}=0.0394$ inch.

VVisual scale: $1=$ severe decline, 5 = fully healthy.

${ }^{\mathrm{x}}$ Means followed by the same letter within each column are not statistically significantly different at $P=0.050$. Trunk diameter was assessed by analysis of variance. All others were assessed by the Kruskal-Wallis test.

also subjected to repeated-measures statistical analysis (Proc Glimmix), but the results were essentially identical to the analysis of variance results (the difference was never more than $0.2 \mathrm{~mm}$, and there were only a few differences in the mean separations); therefore, more intuitive actual means are reported. The budinoculated and ACP-inoculated experiments were analyzed separately. Exclusion of the Aug. 2013 ACPinoculated trees did not affect mean differences; therefore, all ACP-inoculated trees were analyzed as one group.

\section{Results and discussion}

The primary objective of this experiment was to determine if the selection of rootstock could enhance the development of HLB-related symptoms and CLas titer. If so, then it may permit more rapid identification of HLB-susceptible compared to
HLB-resistant scion types. The secondary objective was to assess the impact of different rootstocks on plant growth parameters and health to determine if trees on any rootstocks displayed reduced sensitivity to HLBinfluenced growth restriction.

EFFECTS OF ROOTSTOCK ON Clas-inoculated trees: LeaF BLOTCHY MOTTLE. A blotchy mottle pattern on the leaves of both budinoculated and ACP-inoculated trees was slow to develop, with little mottle observed for as long as 1 year after the initial pathogen exposure (Figs. $1 \mathrm{~A}$ and 2A). By Oct. 2014, most trees in both experiments had nutritional deficiency-like symptoms (data not shown), which often precede the classic blotchy mottle symptoms of the leaves, with an average of $\approx 10 \%$ of leaves affected. Regarding bud-inoculated trees, by Dec. 2016 (Table 1; Fig. 1A), more than $25 \%$ of leaves across all trees had a distinctive blotchy mottle pattern. Trees on UFR-4 were least affected (13\%) compared to trees on Green-7 $(31 \%)$, Carrizo (33\%), rough lemon (33\%), and US-897 (38\%). However, by Dec. 2016, in the ACP-inoculated experiment (Table 2; Fig. 2A), trees on US-897 had the highest level of blotchy mottle on the leaves $(61 \%)$; that level was significantly higher than those of trees on any other rootstock except for UFR-2 (44\%) and rough lemon $(43 \%)$, placing trees on US-897, UFR-2 and rough lemon consistently in the highest mottle inducing group. It is not clear how these results are related to the biology of HLB tolerance because several studies have reported that the highest levels of mottle have been observed on scions with significant HLB tolerance (Miles et al., 2017; Stover et al., 2015).

EFFECTS OF ROOTSTOCK ON CLAS-INOCULATED TREES: GROWTH. Due to inherent differences in vigor, 
trees on sour orange and rough lemon had the largest trunk diameter; these diameters remained the largest throughout each study (Figs. IB and $2 \mathrm{~B})$. In the ACP-inoculated experiment, trees on US-897 were not statistically different in size from trees on rough lemon (Fig. 2B). These statistical differences were largely sustained throughout each experiment. When the monthly percentage increase in the trunk diameter (relative growth rate) was calculated, a slightly different result was observed. Although in both experiments there was no statistical difference in relative growth rates of the trunk during five of the nine growth assessments for the ACP-inoculated experiment, trees on UFR-2 exhibited the highest growth rate in June 2014, Aug. 2014, and Aug. 2015, and their mean permonth growth rate was higher than those of all other rootstocks except UFR-4 when assessed across the entire experiment through Dec. 2016 (Fig. 2C; Table 2). Results were very similar for the bud-inoculated experiment (Fig. 1C; Table 1). It should be noted that the potting medium used includes mycorrhizal fungi that could affect plant growth and there may have been an interaction between rootstock genotype and formation of mycorrhizal associations, rather than all growth effects resulting from HLBrelated rootstock effects. It is also possible that some effects may have reflected specific interactions between the scion and rootstocks (Garnsey et al., 2001). Citrus rootstocks are known to influence drought response (Pompeu and Blumer, 2014), and the effects of transient and invisible water deficiencies alone or in combination with HLB-derived stress may have influenced the observed rootstock effects on growth.

EFFECTS OF ROOTSTOCK ON Clas-inoculated trees: Tree MORTALITY AND HEALTH OF SURVIVING TREES. Mortality across both experiments ranged from $9 \%$ to $37 \%$ for trees budded on individual rootstocks; however, no data regarding the apparent cause of death were recorded. On Dec. 2016, trees on Green-7, UFR-4, and sour orange had significantly lower mortality than trees on US897 in the bud-inoculated study (Table 1 ), whereas trees on Carrizo had lower mortality than UFR-2 in the ACP-inoculated trial
(Table 2). During the Apr. 2016 data collection, no more than three trees had been lost on any rootstock in either experiment except for US897 in the bud-inoculated experiment and rough lemon in the ACP-inoculated experiment (data not shown). Trees on almost all rootstocks showed additional mortality during the summer and fall of 2016, which may have been associated with a hurricane-associated shutdown (5 through 9 Oct.) that partially disrupted greenhouse care, although some watering occurred during this period. It may be noteworthy that when data from the two experiments were combined in a single analysis, trees on US897 and rough lemon had the highest mortality at the time of the first data collection on Apr. 2015, and this continued through Apr. 2016.

Our experience is that citrus trees seldom die from HLB alone, and that diseased trees are more susceptible to other stresses. Affinity between specific scions and rootstocks is complex and difficult to predict. Even among frequently grown scions and rootstocks, some combinations do not perform as well as others. For example, the most widely used rootstock in Florida, Swingle ( $C$. paradisi $\mathrm{x} P$. trifoliata), does not perform well with the 'Pera' sweet orange scion (Garnsey et al., 2001); however, the 'Valencia' sweet orange performs well on this rootstock. Tree survival in a commercial nursery is very high, but it is routine for $10 \%$ to $15 \%$ of trees to have substandard growth that prevents their commercial use (BriteLeaf Nursery, unpublished data).

A visual tree health analysis involving all surviving trees was performed in Dec. 2016. Using the 5 -point subjective scale, trees on UFR-4 had the highest health score in both experiments, had health scores that were significantly greater than those for trees on Carrizo and US-897 in both experiments, had scores that were significantly greater than those for trees on Green-7 and sour orange in the bud-inoculated experiment, and had scores that were significantly greater than those of trees on rough lemon in the ACPinoculated experiment (Tables 1 and 2 ). The health scores were not significantly different among UFR-2, UFR-4, and Cleopatra in both experiments.
Trees on Carrizo comprised the lowest percentage of trees in health categories 3 through 5 in the ACP trial $(37 \%)$, which was significantly higher for sour orange (95\%), UFR-2 (89\%), and UFR-4 (76\%). US-897 had the lowest percentage $(57 \%)$ of trees in health categories 3 through 5 in the budinoculated trial, with only UFR-4 having a better percentage (86\%).

EFFECTS OF ROOTSTOCK ON Clas-inoculated trees: Clas TITER. In the bud-inoculated experiment (Table 3), leaves of 'Valencia' on UFR-4 had the lowest CLas titer, as indicated by PCR [lower cycle threshold $(\mathrm{Ct})$ indicates higher titer] on both tested dates. This titer value was significantly lower than that of trees on UFR-2, rough lemon, and US-897 on 14 Dec.; it was only lower than that of trees on rough lemon on 15 Dec. Regarding UFR-4, 50\% of trees had Ct $>36$ on 14 Dec. and 62\% on 15 Dec., with several rootstocks (Carrizo, Cleopatra, and rough lemon on 14 Dec.; Cleopatra and rough lemon on 15 Dec.) showing a significantly lower percentage of trees with $\mathrm{Ct}>36$. Regarding the bud-inoculated trees, the root CLas titer was lowest for Cleopatra, with $42 \%$ of trees having $\mathrm{Ct}>36$, and significantly lower than for UFR-2, UFR-4, sour orange, and US-897.

In the ACP-inoculated experiment (Table 4), leaves of 'Valencia' on Carrizo, UFR-2, and UFR-4 had the highest CLas titer on 14 Dec., whereas trees on rough lemon had the highest titer on $15 \mathrm{Dec}$. Sour orange had the highest percentage of trees with $\mathrm{Ct}>36$ on 14 and $15 \mathrm{Dec}$., with several rootstocks showing a significantly lower percentage of trees with $\mathrm{Ct}>36$, which was inconsistent between the two dates. For the ACPinoculated trees, the root CLas titer was lowest for Cleopatra, Carrizo, rough lemon, and sour orange; $56 \%$ of trees on rough lemon had Ct $>36$. The percentages were significantly lower for Green-7, UFR-2, UFR-4, and US-897.

As a measure of inoculation success, we analyzed the percentage of trees with $\mathrm{Ct}<36$ in any tissue at any time point. In both experiments, sour orange had the lowest percentage of trees with $\mathrm{Ct}<36(88 \%)$, whereas most other rootstocks had percentages of $96 \%$ to $100 \%$ (Tables 3 and 4). These values represent 
Table 3. Huanglongbing pathogen titer for 'Valencia' sweet orange leaves and roots on eight rootstocks following bud inoculation with Candidatus Liberibacter asiaticus. Huanglongbing pathogen titer is presented as cycle threshold (Ct) according to the polymerase chain reaction (PCR). Percentage of samples with $\mathrm{Ct}>36$ at each time point and percentage of samples with $\mathrm{Ct}<36$ at any time during the study are shown. ${ }^{\mathrm{z}}$

\begin{tabular}{|c|c|c|c|c|c|c|c|}
\hline Rootstock & $\begin{array}{c}\text { Leaves Dec. } \\
2014(\mathrm{Ct})\end{array}$ & $\begin{array}{c}\text { Leaves Dec. } \\
2015(\mathrm{Ct})\end{array}$ & $\begin{array}{l}\text { Roots Dec. } \\
2015(\mathrm{Ct})\end{array}$ & $\begin{array}{c}\text { Leaves Dec. } \\
2014(\%>36 \mathrm{Ct})\end{array}$ & $\begin{array}{c}\text { Leaves Dec. } \\
2015(\%>36 \mathrm{Ct})\end{array}$ & $\begin{array}{c}\text { Roots Dec. } \\
2015(\%>36 \mathrm{Ct})\end{array}$ & $\begin{array}{c}\text { Trees at any } \\
\text { time }(\%<36 \mathrm{Ct})^{\mathrm{y}}\end{array}$ \\
\hline Carrizo & $31 a-c^{x}$ & $32 \mathrm{ab}$ & $33 \mathrm{ab}$ & $14 \mathrm{c}$ & $40 \mathrm{ab}$ & $28 \mathrm{a}-\mathrm{c}$ & $100 \mathrm{a}$ \\
\hline Cleopatra & $31 \mathrm{a}-\mathrm{c}$ & $31 \mathrm{ab}$ & $34 \mathrm{a}$ & $20 \mathrm{bc}$ & $29 \mathrm{~b}$ & $42 \mathrm{a}$ & $96 \mathrm{ab}$ \\
\hline Green-7 & $33 \mathrm{ab}$ & $32 \mathrm{ab}$ & $33 \mathrm{ab}$ & $47 \mathrm{a}$ & $42 \mathrm{ab}$ & $26 \mathrm{a}-\mathrm{c}$ & $89 \mathrm{ab}$ \\
\hline Rough lemon & $28 \mathrm{c}$ & $28 \mathrm{~b}$ & $32 \mathrm{ab}$ & $18 \mathrm{bc}$ & $26 \mathrm{~b}$ & $30 \mathrm{ab}$ & $100 \mathrm{a}$ \\
\hline Sour orange & $32 \mathrm{ab}$ & $30 \mathrm{ab}$ & $30 \mathrm{bc}$ & $42 \mathrm{ab}$ & $41 \mathrm{ab}$ & $25 \mathrm{a}-\mathrm{c}$ & $88 \mathrm{~b}$ \\
\hline US-897 & $29 \mathrm{bc}$ & $32 \mathrm{ab}$ & $27 \mathrm{~d}$ & $28 \mathrm{a}-\mathrm{c}$ & $39 \mathrm{ab}$ & $5 \mathrm{c}$ & $100 \mathrm{a}$ \\
\hline
\end{tabular}

${ }^{\mathrm{z}} \mathrm{Ct}$ corresponds to genomes of CLas per microgram DNA as follows: $26=142,000 ; 30=11,500 ; 34=930$ (conversion as described by Stover et al., 2015 ); 1 genome/ $\mu \mathrm{g}=$ $2.8571 \times 10^{7}$ genomes/oz.

${ }^{y}$ Percentage is greater than suggested by the data shown because the category of some plants changed $(<36$ vs. $>36)$ between tissues and times

${ }^{\mathrm{x}}$ Means followed by the same letter within each column are not statistically significantly different at $P=0.050$. All data were assessed by the Kruskal-Wallis test.

Table 4. Huanglongbing pathogen titer for 'Valencia' sweet orange leaves and roots on eight rootstocks following inoculation with Candidatus Liberibacter asiaticus through feeding by asian citrus psyllid. Huanglongbing pathogen titer is presented as cycle threshold (Ct) according to polymerase chain reaction (PCR). Percentage of samples with Ct $>36$ shown at each time point and percentage of samples with $\mathrm{Ct}<36$ at any time during the study are shown. ${ }^{\mathrm{z}}$

\begin{tabular}{|c|c|c|c|c|c|c|c|}
\hline Rootstock & $\begin{array}{c}\text { Leaves Dec. } \\
2014(\mathrm{Ct})\end{array}$ & $\begin{array}{c}\text { Leaves Dec. } \\
2015(\mathrm{Ct})\end{array}$ & $\begin{array}{l}\text { Roots Dec. } \\
2015(\mathrm{Ct})\end{array}$ & $\begin{array}{c}\text { Leaves Dec. } 2014 \\
\quad(\%>36 \mathrm{Ct})\end{array}$ & $\begin{array}{l}\text { Leaves Dec. } 2015 \\
\quad(\%>36 \mathrm{Ct})\end{array}$ & $\begin{array}{l}\text { Roots Dec. } 2015 \\
\quad(\%>36 \mathrm{Ct})\end{array}$ & $\begin{array}{l}\text { Trees at any time } \\
\quad(\%<36 \mathrm{Ct})^{\mathrm{y}}\end{array}$ \\
\hline Carrizo & $26 b^{x}$ & $29 \mathrm{ab}$ & $34 \mathrm{a}$ & $10 \mathrm{~d}$ & $24 \mathrm{ab}$ & $33 \mathrm{ab}$ & $100 \mathrm{a}$ \\
\hline Cleopatra & $30 \mathrm{a}$ & $31 \mathrm{ab}$ & $35 \mathrm{a}$ & $39 a-c$ & $22 \mathrm{~b}$ & $32 \mathrm{ab}$ & $92 \mathrm{ab}$ \\
\hline Green-7 & $31 \mathrm{a}$ & $31 \mathrm{ab}$ & $27 \mathrm{~b}$ & $32 \mathrm{a}-\mathrm{d}$ & $39 \mathrm{ab}$ & $6 c$ & $100 \mathrm{ab}$ \\
\hline Rough lemon & $30 \mathrm{a}$ & $27 \mathrm{~b}$ & $35 a$ & $41 \mathrm{ab}$ & $24 \mathrm{ab}$ & $56 a$ & $91 \mathrm{ab}$ \\
\hline Sour orange & $33 a$ & $33 a$ & $34 \mathrm{a}$ & $58 \mathrm{a}$ & $50 \mathrm{a}$ & $35 \mathrm{ab}$ & $88 \mathrm{~b}$ \\
\hline US-897 & $31 \mathrm{a}$ & $30 \mathrm{ab}$ & $28 \mathrm{~b}$ & $38 \mathrm{a}-\mathrm{c}$ & $19 \mathrm{~b}$ & $6 \mathrm{c}$ & $96 \mathrm{ab}$ \\
\hline
\end{tabular}

${ }^{\mathrm{z}}$ Ct corresponds to genomes of CLas per microgram of DNA as follows: $26=142,000 ; 30=11,500 ; 34=930$ (conversion as described by Stover et al., 2015 ); 1 genome $/ \mu \mathrm{g}=$ $2.8571 \times 10^{7}$ genomes $/ \mathrm{oz}$.

${ }^{\mathrm{y}}$ Percentage is greater than suggested by the data shown because the category of some plants changed $(<36$ vs. $>36)$ between tissues and times

${ }^{x}$ Means followed by the same letter within each column are not statistically significantly different at $P=0.050$. All data were assessed by the Kruskal-Wallis test.

a very high success rate for CLas inoculation.

\section{Conclusions}

Compared with Carrizo, no rootstock conferred accelerated identification of HLB susceptibility; blotchy mottle symptoms on leaves developed late on all trees (Figs. 1A and 2A). By Dec. 2016, the percentage of mottled leaves was greatest for trees on US897 in both trials (Tables 1 and 2), but trees on this rootstock did not show diminished health or growth compared with trees on Carrizo. However, findings related to our secondary objective of assessing the impact of different rootstocks on plant growth and health parameters were interesting. In both experiments, 'Valencia' on sour orange and rough lemon had the largest trunk diameters, as did trees on US-897 in the ACP trial (Figs. 1B and 2B). Percentage monthly increase in trunk diameter over the entire experiments was significantly greater for UFR-2 with only UFR-4 not significantly lower (Figs. IC and 2C). In Dec. 2016, UFR-4 had the highest health score; this score was significantly better than that of Carrizo and US-897 in both trials, but not different from those of several other rootstocks (Tables 1 and 2 ). There was no clear pattern linking putative measures of HLB tolerance and CLas titer. The industry would greatly benefit from the use of rootstocks that confer HLB tolerance to susceptible scions because it would help achieve "economic tolerance" that would permit sustainable and profitable citrus production in the presence of HLB (Castle et al., 2015). However, it is not known whether the modest differences in health and growth observed in these greenhouse trials will translate to marked economic benefits in the field. These data do suggest that genetic variability regarding the ability to mitigate HLB severity in scions may exist within rootstock germplasm. With focused breeding and selection, it may be possible to develop new rootstocks that confer higher levels of tolerance.

\section{Literature cited}

Albrecht, U. 2017. Rootstocks and HLB tolerance-another perspective. 17 Aug. 2018. <http://citrusindustry.net/ 2017/08/21/rootstocks-hlb-toleranceanother-perspective/ $>$.

Albrecht, U. and K.D. Bowman. 2008. Gene expression in Citrus sinensis (L.) Osbeck following infection with the bacterial pathogen Candidatus Liberibacter asiaticus causing huanglongbing in Florida. Plant Sci. 175:291-306. 
Albrecht, U. and K.D. Bowman. 2011. Tolerance of the trifoliate citrus hybrid US-897 (Citrus reticulata Blanco $\times$ Poncirus trifoliata L. Raf.) to huanglongbing. HortScience 46:16-22.

Albrecht, U., G. McCollum, and K.D. Bowman. 2012. Influence of rootstock variety on huanglongbing disease development in field-grown sweet orange (Citrus sinensis [L.] Osbeck) trees. Scientia Hort. 138:210-220.

Bové, J.M. 2006. Huanglongbing: A destructive, newly-emerging, century-old disease of citrus. J. Plant Pathol. 88:7-37.

Bowman, K.D., G. McCollum, and U. Albrecht. 2016. Performance of 'Valencia' orange (Citrus sinensis [L.] Osbeck) on 17 rootstocks in a trial severely affected by huanglongbing. Scientia Hort. 201: 355-361.

Castle, B., J. Grosser, K. Bowman, and E. Stover. 2015. An HLB-tolerant citrus rootstock; what exactly does that mean? Citrus Ind. 2015(June):16-19.

Florida Foundation Seed Producers. 2014.9 New citrus rootstocks-descriptions and data. 18 Oct. 2018. <http://www.ffsp.net/wpcontent/uploads /2014/05/CitrusRootstock-Overview.pdf>.

Folimonova, S.Y., C.J. Robertson, S.M. Garnsey, S. Gowda, and W.O. Dawson. 2009. Examination of the responses of different genotypes of Citrus to huanglongbing (citrus greening) under different conditions. Phytopathology 99:1346-1354.

Garnsey, S.M., W.S. Castle, D.P. Tucker, R.E. Rouse, H.K. Wutscher, and M.C. Kesinger. 2001. Budunion incompatibilities and associated declines observed in Florida among trees on Swingle citrumelo and other trifoliate orange-related rootstocks. Proc. Florida State Hort. Soc. 114:121-127.
Gottwald, T.R. 2010. Current epidemiological understanding of citrus huanglongbing. Annu. Rev. Phytopathol. 48:119-139.

Hall, D.G. and K.M. Moulton. 2018. Transmission rates of 'Candidatus Liberibacter asiaticus' to greenhouse seedlings by laboratory colonies of asian citrus psyllid. J. Econ. Entomol. 18:doi: $10.1093 / \mathrm{jee} / \mathrm{toy} 240$.

Kunta, M., J.V. da Graça, N.S.A. Malik, E.S. Louzada, and M. Sétamou. 2014. Quantitative distribution of Candidatus Liberibacter asiaticus in the aerial parts of the huanglongbing-infected citrus trees in Texas. HortScience 49:65-68.

Miles, G.P., E.W. Stover, C. Ramadugu, and R.F. Lee. 2017. Apparent tolerance to huanglongbing in Citrus and Citrusrelated germplasm. HortScience 52:3139.

Pompeu, J.J. and S. Blumer. 2014. Trifoliate hybrids as rootstocks for Pera sweet orange tree. Pesqui. Agropecu. Trop. 44:9-14.

Ramadugu, C., M. Keremane, S. Halbert, Y.-P. Duan, M.L. Roose, E. Stover, and R. Lee. 2016. Long term field evaluation reveals HLB resistance in Citrus relatives. Plant Dis. 100:1858-1869.

Singerman, A. 2016. Citrus production costs-central Florida (Ridge). 18 Oct. 2018. <http://www.crec.ifas.ufl.edu/ extension/economics/central_florida. shtml>.

Singerman, A. and P. Useche. 2015. Impact of citrus greening on citrus operations in Florida. 18 Oct. 2018. <http:// www.crec.ifas.ufl.edu/extension/ economics /pdf/Impact $\% 20$ Citrus $\%$ 20Greening\%20web.pdf $>$.

Stover, E., S. Inch, M. Richardson, and D.G. Hall. 2016a. Conventional citrus of some scion/rootstock combinations show field tolerance under severe huanglongbing disease pressure. HortScience 51:127-132.

Stover, E. and G. McCollum. 2011. Incidence and severity of huanglongbing and Candidatus Liberibacter asiaticus titer among field-infected citrus cultivars. HortScience 46:1344-1348.

Stover, E., G. McCollum, J. Chaparro, and M. Ritenour. 2012. Under severe HLB and citrus canker pressure, 'Triumph' and 'Jackson' perform better than 'Flame' and 'Marsh' grapefruit. Proc. Florida State Hort. Soc. 125:40-46.

Stover, E., G. McCollum, J. Ramos, and R.G. Shatters. Jr. 2015. Growth, health and Liberibacter asiaticus titer in diverse citrus scions on mandarin vs. trifoliate hybrid rootstocks in a field planting with severe huanglongbing. Proc Florida State Hort. Soc. 127:53-59.

Stover, E., R.G. Shatters, Jr., B. Gruber, P. Kumar, and G.A. Moore. 2016b. Influence of photoperiod duration and phloem disruption through scoring on growth, disease symptoms and bacterial titer in citrus graft-inoculated with Candidatus Liberibacter asiaticus. HortScience 51:1215-1219.

U.S. Department of Agriculture. 2018a. Citrus June forecast maturity test results and fruit size. 18 Oct. 2018. <https:// www.nass.usda.gov/Statistics_by_State/ Florida/Publications/Citrus/Citrus_ Forecast/2017-18/cit0618.pdf $>$.

U.S. Department of Agriculture. 2018b. Florida citrus statistics 2016-2017. 18 Oct. 2018. <https://www.nass.usda. gov/Statistics_by_State/Florida/ Publications/Citrus/Citrus_Statistics / 2016-17/fcs1617.pdf>. 